\title{
EDUKASI OBAT DAN MAKANAN AMAN DI KALANGAN SISWA TAMAN KANAK-KANAK
}

\author{
Fatmawati Fenti ${ }^{1)}$, Vina, Dewi, Lenny, Ivan, Ira \\ ${ }^{1)}$ Sekolah Tinggi Farmasi Bandung \\ e-mail :fenti.fatmawati@stfb.ac.id
}

\begin{abstract}
ABSTRAK
Jumlah penduduk yang besar jika tidak diikuti dengan kualitas penduduk yang baik hanya akan menimbulkan masalah dan menjadi beban pembangunan. Salah satu aspek peningkatan kualitas penduduk adalah dengan meningkatan kesehatan penduduknya. Jumlah penduduk yang kompleks memiliki permasalahan yang kompleks pula. Permasalahan pada kedua mitra Pengmas ini terletak pada kekompleksan penduduknya. Mengapa dipilih siswa Taman Kanak-kanak dikarenakan kami ingin meningkatan pengetahuan secara dini mengenai pentingnya kesehatan. Pengetahuan mengenai obat dan makanan yang aman bagi anak-anak sangat perlu untuk disosialisasikan secara dini. Adapun target luaran atau tujuan yang ingin dicapai pada kegiatan Pengabdian Masyarakat ini adalah anak-anak diharapkan dapat meningkatkan keterampilan berpikir dan memahami tentang definisi obat dan cara penggunaan obat serta memahami mengenai jajanan yang sehat dan aman untuk dikonsumsi.
\end{abstract}

Kata Kunci : Makanan Aman, Obat, Taman Kanak-kanak

\section{PENDAHULUAN}

Kegiatan pembelajaran di TK mengutamakan bermain sambil belajar dan belajar sambil bermain. Secara alamiah bermain memotivasi anak untuk mengetahui sesuatu lebih mendalam, dan secara spontan anak mengembangkan kemampuannya (Bredecamp, 1997).

Pendidikan taman kanak-kanak (TK) merupakan bentuk pendidikan untuk rentang usia empat sampai dengan enam tahun. Pendidikan TK bukan pendidikan yang diwajibkan. Namun, apabila kita memaknai lebih mendalam tentang pentingnya pendidikan sejak usia dini, pendidikan TK atau prasekolah merupakan bentuk pendidikan yang sangat penting bagi kehidupan manusia di masa mendatang. Hal ini sesuai dengan ungkapan berbagai tokoh pendidikan anak bahwa pendidikan pada usia dini merupakan tahapan yang sangat fundamental bagi berkembangan dan pendidikan selanjutnya. Bagi guru TK, memahami hakikat pendidikan dan pembelajaran di TK merupakan suatu tuntutan yang sangat mendasar (Masitoh, 2007).

Kualitas sumber daya manusia merupakan indikator kualitas penduduknya. Kualitas penduduk merupakan komponen penting dalam menunjang pembangunan. Penduduk yang berkualitas akan menunjang pembangunan yang lebih baik. Jumlah penduduk yang besar jika tidak diikuti dengan kualitas penduduk yang baik hanya akan menimbulkan masalah dan menjadi beban pembangunan. Adapun kualitas penduduk menurut
PBB dapat dilihat dari tiga aspek yaitu pendidikan, tingkat kesehatan, serta pendapatan. Cara meningkatkan kualitas penduduk salah satunya yaitu melalui peningkatkan kesehatan yang diawali dengan peningkatan pengetahuan secara dini mengenai pentingnya kesehatan.

Edukasil obat dan makanan aman dikalangan siswa taman kanak-kanak menjadi tema pengabdian masyarakat ini. Hal ini menjadi penting dilaksanakan mengingat bahwa salah satu aspek peningkatan kualitas penduduk adalah dengan meningkatan kesehatan penduduknya. Mengapa dipilih siswa Taman Kanak-kanak dikarenakan kami ingin meningkatan pengetahuan secara dini mengenai pentingnya kesehatan. Pengetahuan mengenai obat dan makanan yang aman bagi anak-anak sangat perlu untuk disosialisasikan secara dini. Penggunaan obat yang semakin banyak pada saat ini belum didukung secara optimal dengan pengetahuan masyarakat mengenai cara konsumsi yang baik dan aman. Pemberian informasi yang benar terkait penggunaan obat menjadi kebutuhan masyarakat agar terhindar dari dampak buruk kesehatan diri maupun lingkungan. Begitu pula dengan makanan terutama jajanan anak yang sehat dan aman sangat perlu untuk disosialisasikan secara dini.

Mitra 1 adalah sekolah Taman Kanak-kanak Al Ihwan dimana siswanya berasal dari penduduk sekitar lokasi sekolah tersebut. Lokasi mitra 1 terletak di komplek perumahan Margahayu Raya dimana warganya yang cukup kompleks baik dari segi jumlah 
penduduk maupun perilaku kehidupan bermasyarakatnya.

Mitra 2 adalah sekolah Taman Kanak-kanak Yayasan Beribu dimana siswanya juga berasal dari penduduk sekitar lokasi sekolah tersebut. Lokasi mitra 2 terletak di perumahan padat penduduk kawasan perumahan PT KAI Kiaracondong Bandung.

Permasalahan pada kedua mitra ini terletak pada kekompleksan penduduknya. Penduduk yang kompleks sudah tentu memiliki kualitas sumber daya yang bervariasi diantara penduduknya.

Tujuan dari Program Pengabdian Masyarakat ini adalah untuk meningkatkan keterampilan berpikir siswa Taman Kanak-kanak dan memahami tentang definisi obat dan cara penggunaan obat serta memahami mengenai jajanan yang sehat dan aman untuk dikonsumsi.

Pengetahuan mengenai obat dan makanan yang aman bagi anak-anak sangat perlu untuk disosialisasikan secara dini. Penggunaan obat yang semakin banyak pada saat ini belum didukung secara optimal dengan pengetahuan masyarakat mengenai cara konsumsi yang baik dan aman. Pemberian informasi yang benar terkait penggunaan obat menjadi kebutuhan masyarakat agar terhindar dari dampak buruk kesehatan diri maupun lingkungan. Begitu pula dengan makanan terutama jajanan anak yang sehat dan aman sangat perlu untuk disosialisasikan secara dini.

Solusi yang diharapkan pada kegiatan Pengabdian Masyarakat ini berupa ;

1. Sosialisasi tentang definisi umum obat dan cara penggunaan obat yang disampaikan sesuai dengan kemampuan daya tangkap siswa Taman Kanak-kanak.

2. Sosialisasi mengenai jajanan anak dan bagaimana cara memilih jajanan yang sehat dan aman bagi anak.

Adapun luaran yang dihasilkan dari masing-masing solusi diatas adalah:

1. Peningkatan pengetahuan pada anak-anak dalam memahami tentang definisi obat dan cara penggunaan obat

2. Peningkatan pengetahuan pada anak-anak dalam memahami mengenai jajanan yang sehat dan aman untuk dikonsumsi

\section{METODE KEGIATAN}

Tahapan-tahapan dalam melaksanakan kegiatan pengabdian pada masyarakat ini adalah sebagai berikut:
1. Memberikan kuisioner awal mengenai obat dan jajanan yang sehat bagi nak- anak.

2. Memberikan edukasi tentang obat dan cara penggunaannya serta jajanan sehat melalui media audio visual.

3. Membuat permainan dengan menyisipkan pertanyaan mengenai apa yang telah disampaikan.

\section{HASIL DAN PEMBAHASAN}

Telah dilaksanakan kegiatan Pengabdian pada masyarakat pada bulan September 2017. Mitra 1 adalah sekolah Taman Kanak-kanak Al Ihwan dimana siswanya berasal dari penduduk sekitar lokasi sekolah tersebut. Lokasi mitra 1 terletak di komplek perumahan Margahayu Raya Bandung dimana warganya yang cukup kompleks baik dari segi jumlah penduduk maupun perilaku kehidupan bermasyarakatnya.
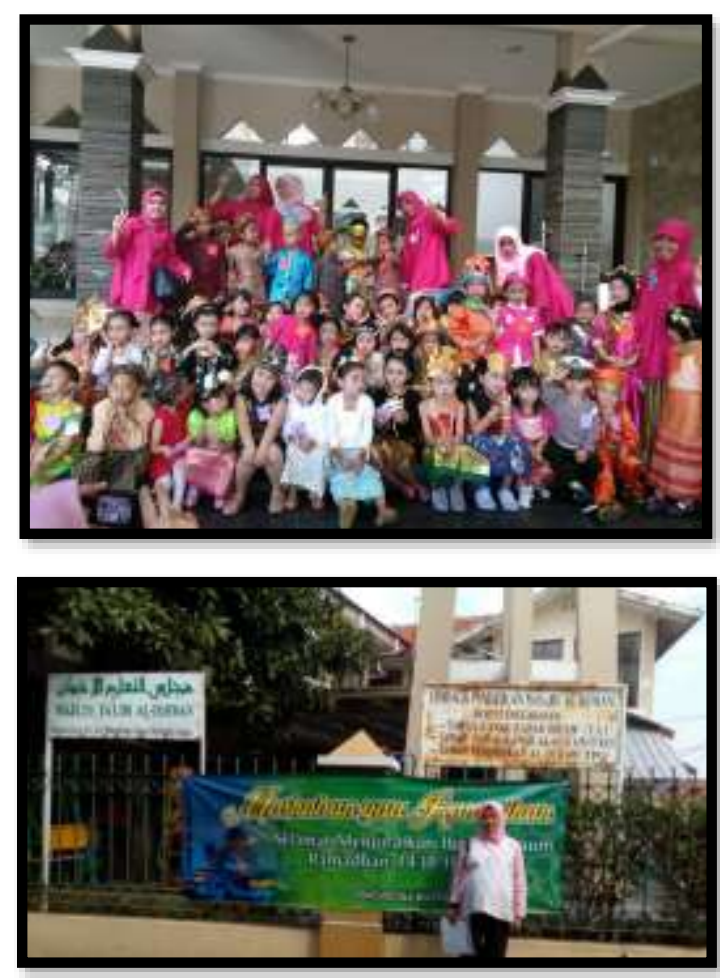

Gambar. 1

Lokasi mitra 1

Sedangkan Mitra 2 adalah sekolah Taman Kanakkanak Yayasan Beribu dimana siswanya juga berasal dari penduduk sekitar lokasi sekolah tersebut. Lokasi mitra 2 terletak di perumahan padat penduduk kawasan perumahan PT KAI Kiaracondong Bandung. 

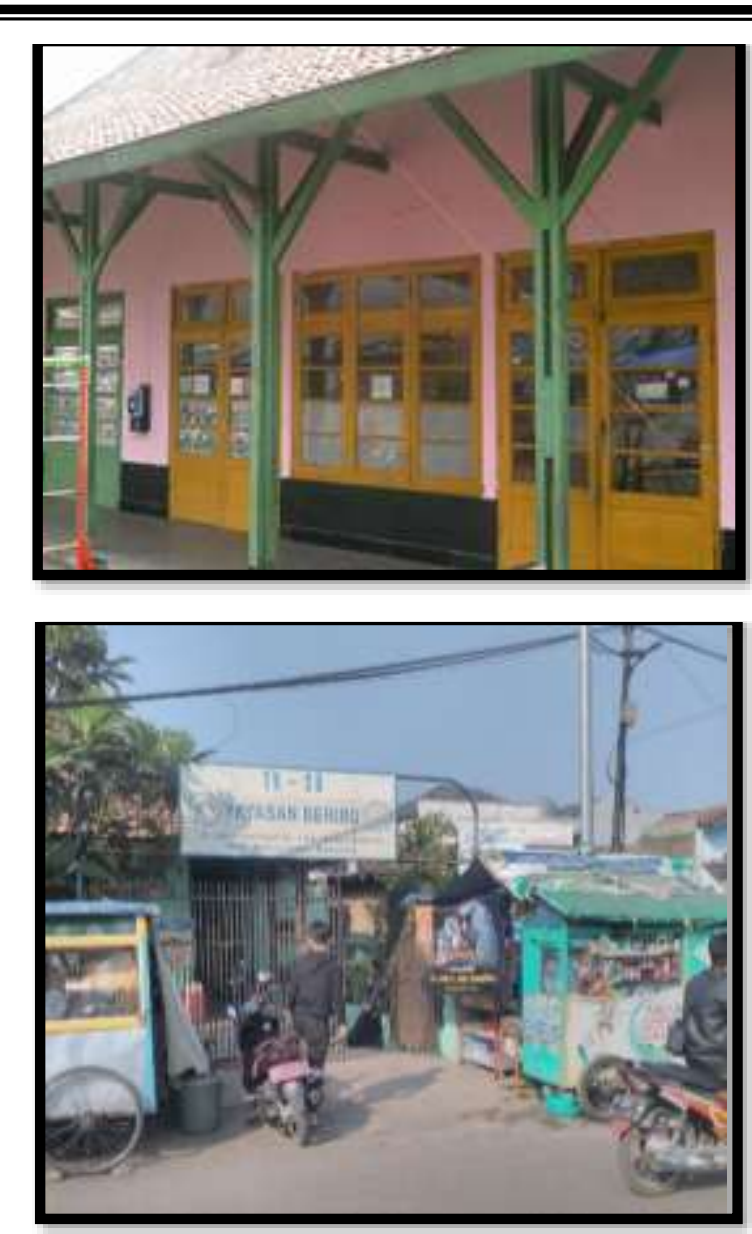

Gambar. 2

Lokasi mitra 2

Tahapan pada kegiatan pengabdian masyarakat ini yaitu sebagai berikut:

1. Pemberian kuisioner awal tentang apa yang mereka ketahui mengenai obat dan jajanan yang sehat bagi anak-anak.

Hal ini bertujuan untuk mengetahui sejauh mana pengetahuan mereka akan obat dan jajanan sehat tersebut. Partisipasi mitra dalam pelaksanaan program ini adalah menyediakan siswa Taman Kanak-kanak yang siap menerima sosialisasi edukasi.

Keuntungan bagi kedua mitra adalah siswa-siswa didik yang dimiliki oleh mitra diharapkan akan memiliki pengetahuan serta memahami akan pentingnya kesehatan, memiliki pengetahuan mengenai obat dan cara penggunaannya serta memiliki pengetahuan mengenai jajanan anak yang sehat dan aman. Pemateri menghangatkan suasana dengan memberikan yel-yel atau nyanyi bersama. Memberikan pertanyaan ringan sebagai awal tentang apa yang mereka ketahui mengenai obat dan jajanan yang sehat bagi anak-anak.

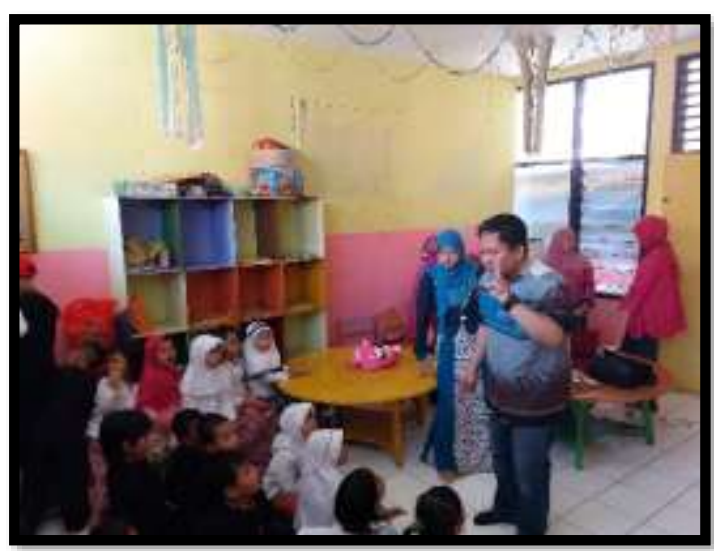

Gambar.3

Pemberian kuisioner mitra 1

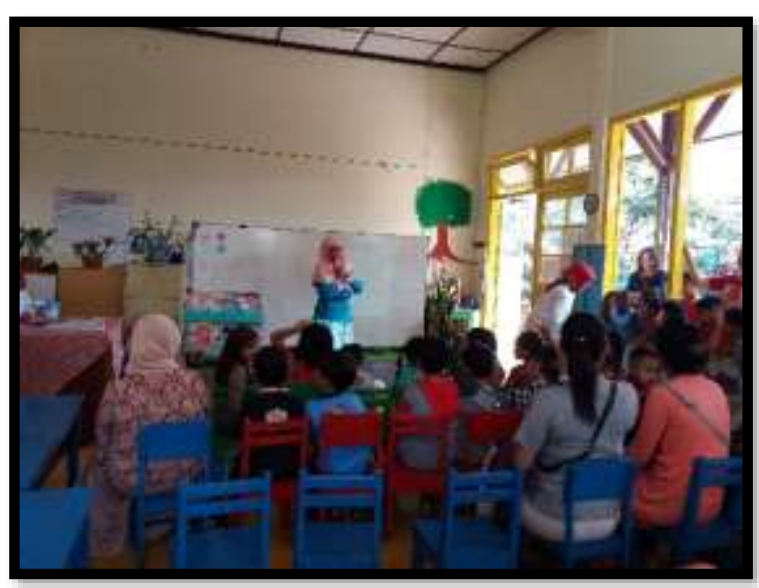

Gambar.4

Pemberian kuisioner mitra 2

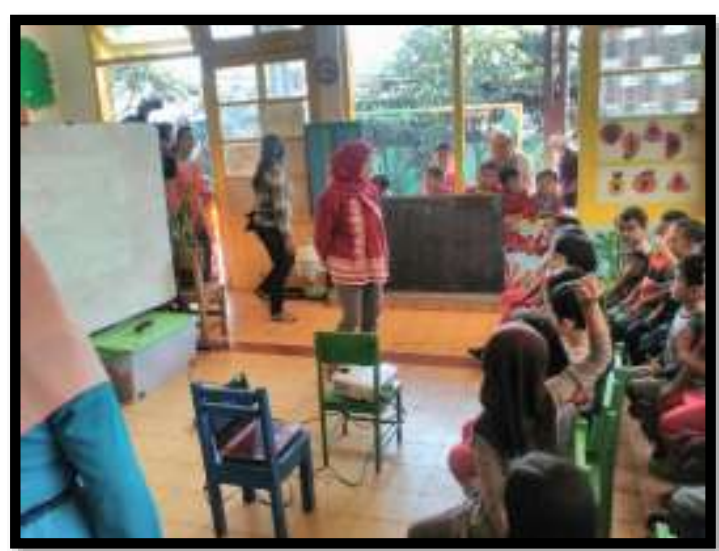

Gambar 5

Pemberian kuisioner mitra 2

2. Pemberian edukasi tentang obat dan cara penggunaannya serta jajanan sehat melalui media audio visual. 
Hal ini dimaksudkan agar pesan dari kegiatan ini dapat tersampaikan kepada siswa. Telah disepakati bersama antara pengusul dan mitra bahwa metode pendekatan yang ditawarkan untuk menyelesaikan persoalan mitra adalah dengan memberikan materi melalui media audio visual dan permainan. Hal ini disesuaikan dengan karakteristik cara belajar anak usia dini.

Anak memiliki karakteristik yang berbeda dengan orang dewasa dalam berperilaku. Dengan demikian dalam hal belajar anak juga memiliki karakteristik yang tidak sama pula dengan orang dewasa. Karakteristik cara belajar anak merupakan fenomena yang harus dipahami dan dijadikan acuan dalam merencanakan dan melaksanakan pembelajaran untuk anak usia dini. Menurut Masitoh (2007), dikatakan bahwa pada pendidikan TK guru TK bertanggung jawab membimbing belajar anak sesuai dengan karakteristik kebutuhan dan perkembangan anak, serta menciptakan kegiatan belajar yang menyenangkan
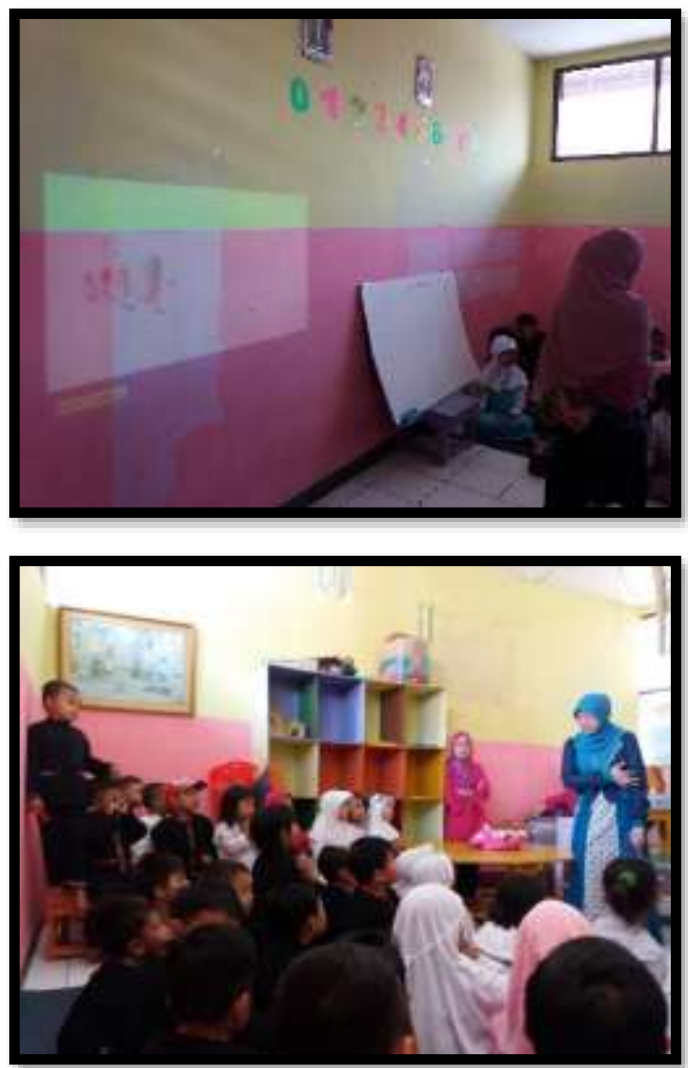

Gambar 6

Pemberian materi mitra 1

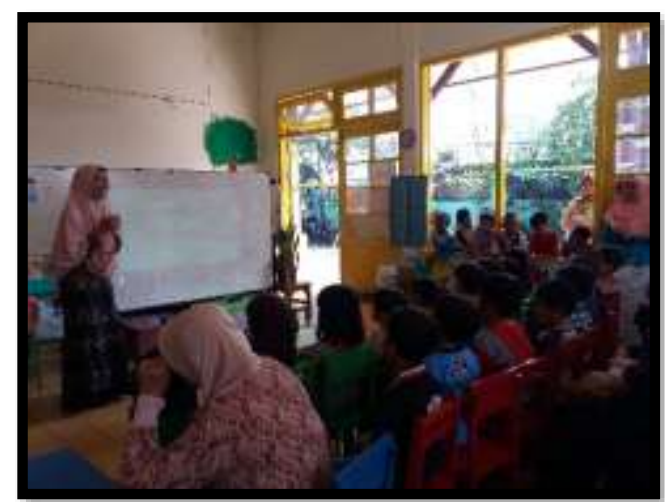

Gambar 7

Pemberian materi mitra 2

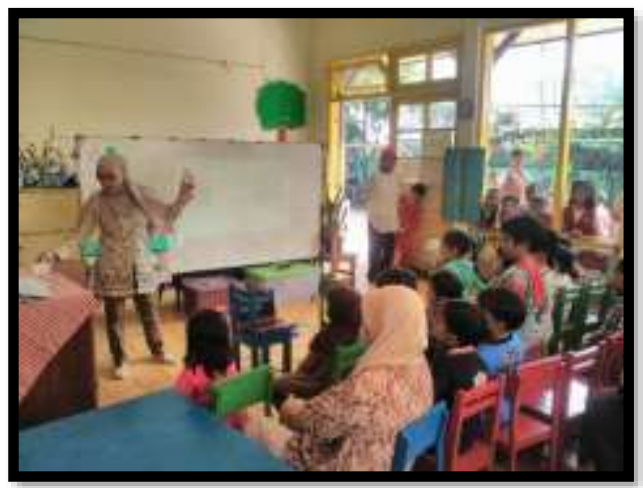

Gambar 8

Pemberian materi mitra 2

3. Membuat permainan dengan menyisipkan pertanyaan mengenai apa yang telah disampaikan.

Hal ini dimaksudkan untuk mengetahui sejauh mana merespon dan memahami apa yang telah disampaikan. Bagi 3 orang anak yang bisa menjawab pertanyaan disediakan doorprize.

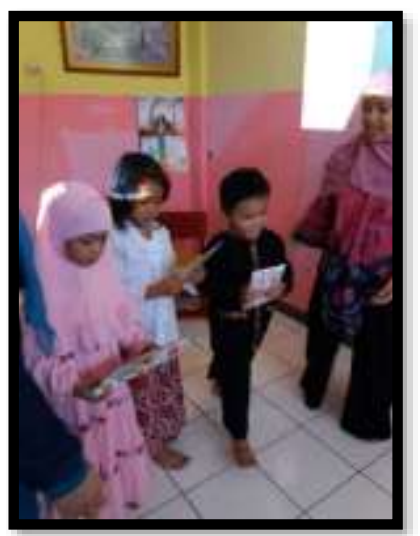

Gambar 9

Pembagian hadiah mitra 1 

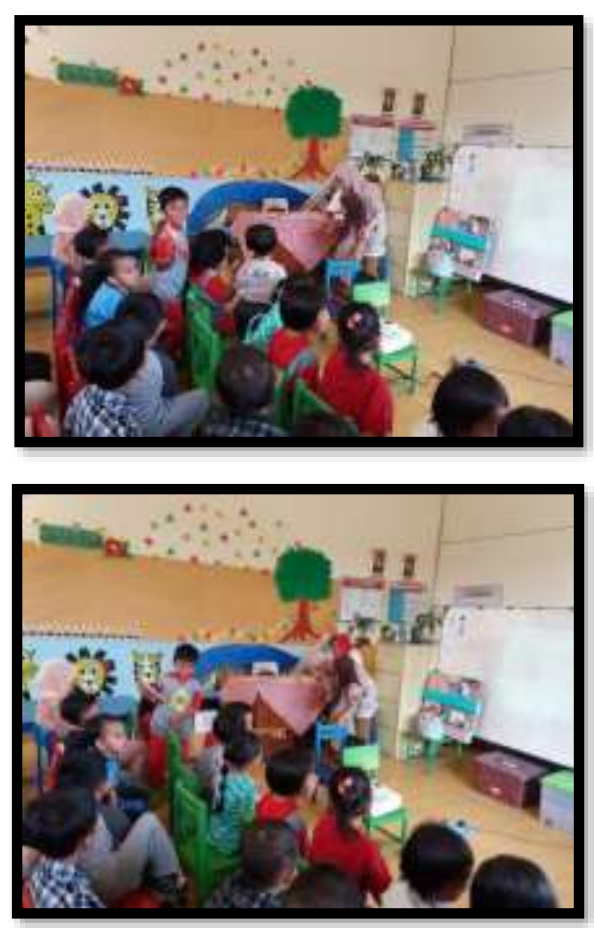

Gambar 10

Pembagian hadiah mitra 2

Akhirnya kegiatan ditutup dengan membagikan makanan sehat untuk siswa Taman Kanank-kanak kedua mitra tersebut.

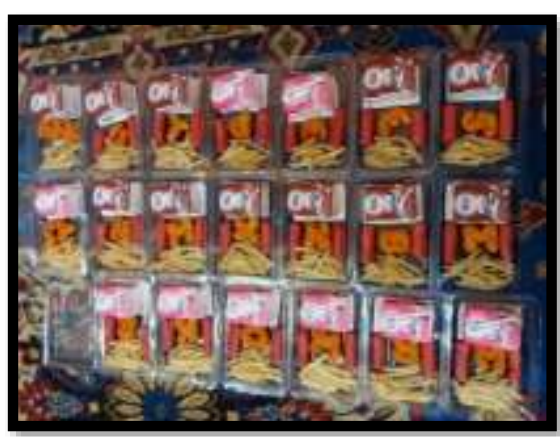

Gambar 11

Makanan sehat yang dibagikan

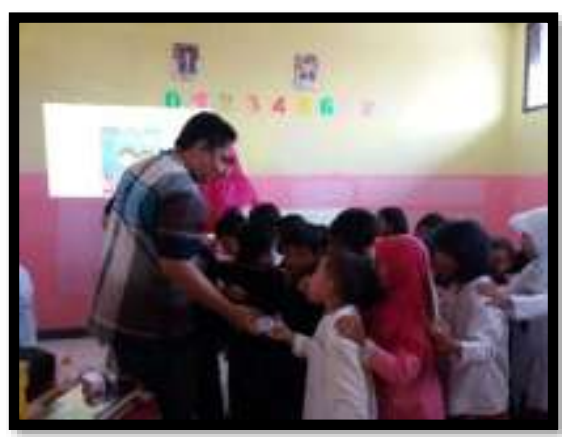

Gambar 12

Pembagian makanan sehat mitra 1

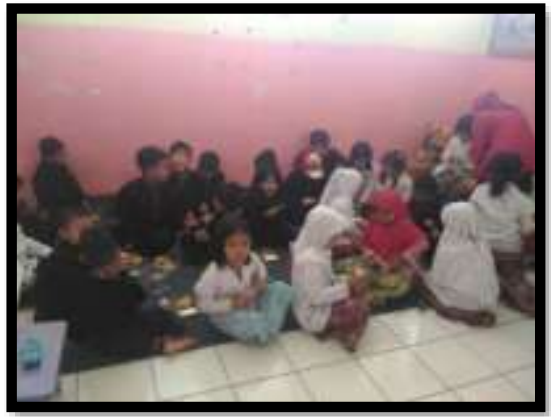

Gambar 13

Makan bersama para siswa TK

Partisipasi mitra dalam pelaksanaan program ini adalah menyediakan siswa Taman Kanak-kanak yang siap menerima sosialisasi edukasi. Keuntungan bagi kedua mitra adalah siswa-siswa didik yang dimiliki oleh mitra diharapkan akan memiliki pengetahuan serta memahami akan pentingnya kesehatan, memiliki pengetahuan mengenai obat dan cara penggunaannya serta memiliki pengetahuan mengenai jajanan anak yang sehat dan aman.

Adapun langkah evaluasi pelaksanaan program dilaksanakan dengan membuat kuisioner pada saat sebelum dan sesudah kegiatan berlangsung. Hal ini untuk melihat sejauh mana respon dan pemahaman siswa akan materi yang diberikan. Keberlanjutan program di lapangan setelah kegiatan PKM selesai dilaksanakan ditinjau secara berkala.

Diharapkan dengan adanya kegiatan pengabdian masyarakat ini dapat terjalin interaksi edukatif yaitu komunikasi timbal balik antara siswa taman kanakkanak dengan tim pengusul kegiatan pengabdian masyarakat yang terarah pada pencapaian tujuan pendidikan. Diharapkan siswa taman kanak-kanak dapat bermain dan belajar dalam situasi yang menyenangkan, atau dalam lingkungan belajar yang telah ditata sedemikian rupa sehingga memungkinkan anak dapat belajar sambil bermain dan bermain sambil belajar.

Acara ditutup dengan foto bersama.

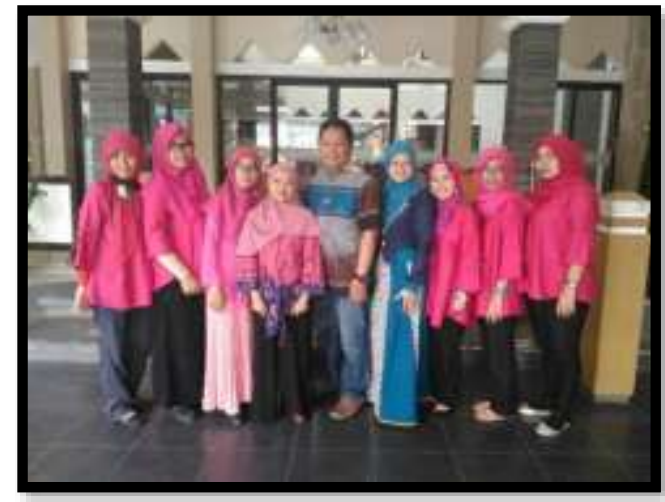

Gambar 11

Foto bersama mitra 1 


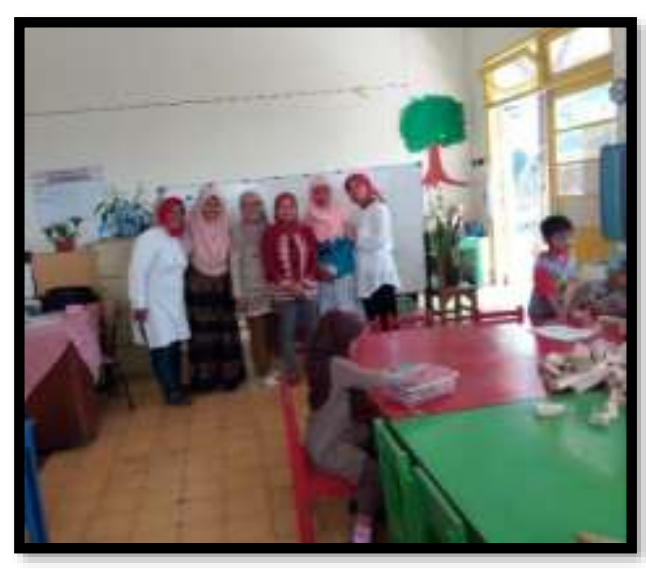

Gambar 12

Foto bersama mitra 2

\section{KESIMPULAN}

Telah dilaksanakan kegiatan Pengabdian pada masyarakat pada bulan September 2017 dengan mitra Taman Kanak-kanak. Mitra 1 adalah Taman Kanakkanak Al Ihwan Bandung yang terletak di komplek perumahan Margahayu Raya Bandung. Sedangkan Mitra 2 adalah sekolah Taman Kanak-kanak Yayasan Beribu yang berlokasi di perumahan padat penduduk kawasan perumahan PT KAI Kiaracondong.

Telah dilaksanakan kegiatan tersebut dengan rangkaian kegiatan :

1. Memberikan kuisioner awal mengenai obat dan jajanan yang sehat bagi anak- anak.

2. Memberikan edukasi tentang obat dan cara penggunaannya serta jajanan sehat melalui media audio visual.

3. Membuat permainan dengan menyisipkan pertanyaan mengenai apa yang telah disam paikan.

Adapun langkah evaluasi pelaksanaan program dilaksanakan dengan membuat kuisioner pada saat sebelum dan sesudah kegiatan berlangsung. Hal ini untuk melihat sejauh mana respon dan pemahaman siswa akan materi yang diberikan. Keberlanjutan program di lapangan setelah kegiatan PKM selesai dilaksanakan ditinjau secara berkala.

Diharapkan dengan adanya kegiatan pengabdian masyarakat ini dapat terjalin interaksi edukatif yaitu komunikasi timbal balik antara siswa taman kanakkanak dengan tim pengusul kegiatan pengabdian masyarakat yang terarah pada pencapaian tujuan pendidikan.

Diharapkan siswa taman kanak-kanak dapat bermain dan belajar dalam situasi yang menyenangkan, atau dalam lingkungan belajar yang telah ditata sedemikian rupa sehingga memungkinkan anak dapat belajar sambil bermain dan bermain sambil belajar.

\section{UCAPAN TERIMA KASIH}

Penulis mengucapkan terima kasih kepada Sekolah Tinggi Farmasi Bandung yang telah memberikan suportnya sehingga kegiatan ini dapat terlaksana dengan lancar.

\section{REFERENSI}

Bredecamp, S. \& Cople, C. (1997). Developmentally Appropriate Practice. USA: National Association for the Young Children.

Masitoh, dkk, 2007. Strategi Pembelajaran TK. Jakarta. Universitas Terbuka SPA, 2003. Menjadi Pendidik Profesional. Jogjakarta Bina nsantana.

Sujiono, Yuliani Nurani. (2009) Konsep Dasar Pendidikan Anak Usia Dini. Jakarta: PT Indeks. 